\title{
Integrasi Generasi Muslim Tanpa Masjid: Kajian Fungsional Arsitektur Masjid Kampus UMS
}

\author{
Andika Saputra ${ }^{1}$ \\ ${ }^{1}$ Prodi Arsitektur, Fakultas Teknik, \\ Universitas Muhammadiyah Surakarta \\ Email: andika.saputra@ums.ac.id
}

\begin{abstract}
ABSTRAK
Generasi Muslim Tanpa Masjid merupakan permasalahan di kalangan umat Islam yang marak terjadi di perkotaan modern di Indonesia, tidak terkecuali di UMS sebagai salah satu institusi pendidikan tinggi Islam di Surakarta. Solusi terhadap permasalahan tersebut ialah integrasi ke dalam jamaah umat Islam melalui peran masjid kampus sebagai pusat kegiatan jamaah kampus di lingkungan perguruan tinggi. Penelitian ini dilakukan untuk menelisik realisasi agenda integrasi Generasi Muslim Tanpa Masjid ke dalam jamaah umat Islam di lingkungan UMS dengan mengidentifikasi kegiatan yang diselenggarakan di masjid kampus, organisasi ruang masjid, strategi yang diterapkan, dan langkah-langkah yang dilakukan dengan memperhatikan aspek kegiatan dan organisasi ruang sebagai variabel penelitian. Penelitian ini menggunakan metode induktif-kualitatif yang merupakan eksperimen dan interpretasi penulis terhadap beragam kegiatan yang diselenggarakan di masjid oleh berbagai civitas akademik UMS. Penelitian menghsilkan tiga temuan. Pertama, kegiatan diselenggarakan untuk menarik keterlibatan Generasi Muslim Tanpa Masjid di masjid kampus meliputi dakwah, pendidikan, olahraga, dan rekreasi yang merupakan fungsi pendukung dengan sifat diwajibkan dan sukarela. Kedua, ruang serbaguna masjid kampus yang merupakan zonasi ruang-antara memiliki peran penting dalam menarik keterlibatan Generasi Muslim Tanpa Masjid berkegiatan di masjid. Ketiga, strategi yang diterapkan ialah sinergi seluruh civitas akademika UMS dengan melakukan dua langkah yang berorientasi pada pembentukan kebiasaan dan integrasi ke dalam jamaah umat Islam dalam skala luas.
\end{abstract}

Kata kunci: generasi muslim tanpa masjid, masjid kampus, integrasi ke dalam jamaah umat Islam

\begin{abstract}
'Generasi Muslim Tanpa Masjid' is a issue among Moslem that is massive in modern cities in Indonesia, including at UMS as one of the Islamic higher education institution in Surakarta. The solution to this issue is integration into the Moslem community trough the role of the university mosque as a center for activities of Moslem community in campus area. This research was conducted to investigate the realization of the agenda integration 'Generasi Muslim Tanpa Masjid' into Moslem community by identifying activities held at university mosque, space organization of university mosque, strategies and steps taken with attention to aspects of activity and space organization as a research variables. This research apply the inductivequalitative method which is the author's experiment and interpretation of various activities held at UMS university mosque by varius parties of UMS academic community. The result of this research consisted three findings. First, activities held at university mosque include the function of dakwah, education, sport, and recreation which are part of second-function of mosque with a mandatory to public and voluntary characteristic. Second, the multipurpose hall of university mosque which is a between-space zoning, has an important space for integration of 'Generasi Muslim Tanpa Masjid' into the Moslem Community. Third, strategy which is applied is synergy of the entire UMS academic community by taking two steps oriented towards building of habit and integration into the Moslem community on a large scale.
\end{abstract}

Keywords: generasi muslim tanpa masjid, university mosque, integration into a Moslem community 


\section{PENDAHULUAN}

\subsection{Latar Belakang}

Kuntowijoyo (2001: 127-129) menemukenali permasalahan keberagamaan umat Islam di perkotaan modern di Indonesia yang disebutnya dengan istilah Generasi Muslim Tanpa Masjid [1]. Berdasarkan pengamatan yang dilakukannya, Kuntowijoyo (2001: 129-131) menetapkan 5 karakter Generasi Muslim Tanpa Masjid. Pertama, lahir di kota-kota besar di Indonesia seperti Jakarta, Bandung, Semarang, Yogyakarta, Surabaya, Makasar, Medan, dan kota-kota serupa, sehingga generasi ini lahir, tumbuh dan berkehidupan di lingkungan perkotaan modern. Kedua, tidak dibesarkan di lingkungan masjid sehingga tidak memiliki kebiasaan untuk berkegiatan rutin di masjid dalam aktivitas kesehariannya yang menyebabkan secara psikologis tidak memiliki kedekatan dengan masjid dan secara sosiologis tidak menjadi bagian dari umat Islam. Ketiga, kebutuhan ruhani maupun kegiatan keagamaan dipenuhi oleh Seksi Kerohanian Islam (KAI) di tingkat sekolah menengah maupun di lingkungan perguruan tinggi. Karakter ketiga ini menunjukkan bahwa Generasi Muslim Tanpa Masjid lahir dari keluarga awam agama, sehingga pengajaran agama baru didapatkan pada usia remaja di luar lingkungan keluarga. Keempat, Generasi Muslim Tanpa Masjid mempelajari Islam tidak melalui institusi pendidikan Islam tradisional seperti madrasah atau pondok pesantren dengan masjid sebagai pusat aktivitas pendidikan, dan tidak pula memiliki hubungan personal yang dekat dengan pemilik otoritas agama. Generasi ini mempelajari Islam melalui media televisi, radio, buku, kaset, dan internet. Sementara itu hubungan Generasi Muslim Tanpa Masjid dengan guru agama di sekolah atau dosen agama Islam di perguruan tinggi sebatas bersifat formal-administratif yang menyebabkan tidak terbentuk ikatan personal-emosial yang kuat layaknya hubungan antara kiai-santri atau guru-murid dalam pendidikan tradisional. Kelima, memiliki semangat pemberontakan terhadap otoritas agama dan politik sebagai sublimasi dari semangat pemberontakan terhadap otoritas generasi tua. Dari lima ciri tersebut dapat disimpulkan bahwasanya Generasi Muslim Tanpa Masjid ialah generasi yang tidak memiliki ikatan personal, sosial, dan intelektual dengan masjid. Dampaknya menurut Kuntowijoyo (2001: 130), Generasi Muslim Tanpa Masjid mengalami krisis identitas sebagai seorang Muslim yang tidak dibesarkan di lingkungan masjid, krisis sosial karena merasa bukan bagian dari umat Islam, dan krisis intelektual karena pengetahuan yang dikuasainya dibentuk oleh dominasi institusi sekolah dan perguruan tinggi, bukan masjid yang merupakan institusi khas Islam.

Generasi Muslim Tanpa Masjid sebagai fenomena keberagamaan di kalangan umat Islam di Indonesia yang diulas oleh Kuntowijoyo pada awal tahun 2000, hingga tahun 2020 belum nampak akan hilang karena masih marak tumbuh di lingkungan perkotaan modern, yang salah satunya dapat ditemui di lingkungan perguruan tinggi. Tidak terkecuali di lingkungan Universitas Muhammadiyah Surakarta (UMS) yang merupakan institusi perguruan tinggi Islam di lingkungan Surakarta sebagai salah satu kota modern di Indonesia.

Maraknya kehadiran Generasi Muslim Tanpa Masjid di lingkungan Perguruan Tinggi Muhammadiyah (PTM) sebagai insitusi perguruan tinggi Islam di Indonesia, di antaranya adalah UMS, dilatarbelakangi dua hal. Pertama, Persyarikatan Muhammadiyah sebagai Ormas Islam dan PTM sebagai bagian dari Muhammadiyah, menurut Kuntowijoyo $(2006: 38,134)$ lekat dengan citra kehidupan urban, budaya kota, dan kalangan menengah kota, sehingga memiliki kedekatan identitas dengan Generasi Muslim Tanpa Masjid yang lahir dan tumbuh di lingkungan perkotaan modern [2]. Kedua, PTM, salah satunya adalah UMS, cenderung merupakan pilihan kedua bagi kalangan pemuda Muslim di lingkungan perkotaan modern setelah Perguruan Tinggi Negeri (PTN) untuk melanjutkan pendidikan di jenjang perguruan tinggi. Salah satu faktor penyebabnya ialah kedekatan identitas sebagaimana dijelaskan pada poin pertama sebelumnya. Dengan demikian keberadaan Generasi Muslim Tanpa Masjid di lingkungan Perguruan Tinggi Muhammadiyah merupakan tantangan dakwah bagi Persyarikatan Muhammadiyah, dan keberadaannya di lingkungan Universitas Muhammadiyah Surakarta merupakan tanggungjawab bagi seluruh civitas akademika kampus untuk menanggapinya sebagai bagian dari permasalahan kehidupan umat Islam di lingkungan perkotaan modern di Indonesia. 
Untuk menanggapi permasalahan tersebut, Kuntowijoyo (2001: 132-134) menawarkan solusi integrasi Generasi Muslim Tanpa Masjid ke dalam jamaah umat Islam melalui empat cara. Pertama, keberadaan jamaah kampus meliputi seluruh civitas akademika di tingkat perguruan tinggi sebagai modal sosial untuk membentuk lingkar studi keislaman di lingkungan perguruan tinggi. Kedua, keberadaan masjid kampus yang berperan sebagai pusat kegiatan lingkar studi keislaman di lingkungan perguruan tinggi. Ketiga, organisasi Islam yang berperan menghubungkan jamaah kampus yang berpusat di masjid kampus dengan masyarakat Muslim dalam skala luas di luar lingkungan kampus. Keempat, integrasi materi keislaman dengan materi ilmu pengetahuan dan teknologi modern sebagai muatan pendidikan agama Islam di tingkat perguruan tinggi.

Penelitian ini dengan pendekatan arsitektur fokus pada poin kedua dari solusi yang disampaikan oleh Kuntowijoyo untuk menanggapi permasalahan Generasi Muslim Tanpa Masjid dengan menempatkan masjid kampus sebagai bagian dari lingkungan binaan. Ditinjau secara arsitektural, peran masjid kampus dalam merealisasikan agenda integrasi Generasi Muslim Tanpa Masjid ke dalam jamaah umat Islam merujuk pada aspek kegiatan atau peruntukan fungsi masjid kampus dan organisasi ruang masjid yang merupakan zonasi dan konfigurasi tata ruang masjid berdasarkan peruntukan fungsinya. Dikaitkan dengan lokus penelitian, tujuan dilakukannya kegiatan penelitian adalah untuk menelisik peran masjid kampus UMS dalam merealisasikan agenda integrasi Generasi Muslim Tanpa Masjid ke dalam jama'ah kampus dengan memperhatikan aspek (1) kegiatan atau peruntukan fungsi masjid kampus; dan (2) organisasi ruang masjid kampus.

Dengan melihat fenomena Generasi Muslim Tanpa Masjid sebagai permasalahan keagamaan dari sudut pandang arsitektur, penelitian ini menetapkan rumusan masalah sebagai berikut:

1. Kegiatan apa saja dan seperti apa yang diselenggarakan civitas akademika UMS di masjid kampus UMS untuk menarik keterlibatan Generasi Muslim Tanpa Masjid berkegiatan di masjid kampus?

2. Seperti apa organisasi ruang masjid kampus UMS untuk mewadahi kegiatan sebagaimana dimaksud pada poin pertama di atas dalam konteks menanggapi permasalahan Generasi Muslim Tanpa Masjid di lingkungan UMS?

3. Apa strategi dan apa saja langkah-langkah yang dilakukan civitas akademika UMS dalam upaya merealisasikan agenda integrasi Generasi Muslim Tanpa Masjid ke dalam jamaah umat Islam di lingkungan UMS?

Penelitian ini merupakan eksperimentasi yang dilakukan penulis dalam rangka mengkaji sekaligus merealisasikan solusi yang disampaikan Kuntowijoyo, serta interpretasi penulis terhadap berbagai kegiatan di masjid kampus UMS yang diselenggarakan oleh berbagai pihak civitas akademika UMS dikaitkan dengan peran masjid kampus UMS dalam merealisasikan agenda integrasi Generasi Muslim Tanpa Masjid ke dalam jamaah umat Islam. Eksperimentasi dan interpretasi tersebut dilakukan untuk menemukan jawaban atas rumusan masalah yang merupakan tujuan dari penelitian ini, yakni sebagai berikut:

1. Mengidentifikasi jenis dan karakter kegiatan yang diselenggarakan civitas akademika UMS di masjid kampus UMS untuk menarik keterlibatan Generasi Muslim Tanpa Masjid berkegiatan di masjid kampus.

2. Mengetahui konfigurasi organisasi ruang masjid kampus UMS untuk mewadahi kegiatan dalam konteks menanggapi permasalahan Generasi Muslim Tanpa Masjid di lingkungan UMS.

3. Mengidentifikasi strategi dan langkah-langkah yang dilakukan civitas akademika UMS dalam upaya merealisasikan agenda integrasi Generasi Muslim Tanpa Masjid ke dalam jamaah umat Islam di lingkungan UMS.

Hasil penelitian ini bermanfaat bagi tiga pihak. Pertama, bagi pihak pengelola masjid kampus UMS dan masjid kampus di lingkungan perguruan tinggi lainnya di Indonesia, hasil penelitian ini merupakan masukan, panduan, sekaligus evaluasi untuk meningkatkan peran masjid kampus dalam upaya menanggapi fenomena Generasi Muslim Tanpa Masjid yang marak terjadi di kota-kota besar di 
Indonesia hingga hari ini. Kedua, bagi pihak perencana dan perancang arsitektur, hasil penelitian ini dapat dijadikan sebagai pertimbangan dan panduan dalam mengambil keputusan desain terkait aspek organisasi ruang masjid kampus yang tanggap terhadap permasalahan Generasi Muslim Tanpa Masjid. Ketiga, bagi jamaah kampus, terutama di lingkungan Universitas Muhammadiyah Surakarta, hasil penelian ini dapat menumbuhkan kesadaran terhadap permasalahan Generasi Muslim Tanpa Masjid, sehingga diharapkan dapat melibatkan diri untuk merealisasikan agenda integrasi generasi tersebut ke dalam jamaah umat Islam di lingkungan kampus dan dalam skala yang lebih luas.

Kajian terhadap fenomena Generasi Muslim Tanpa Masjid merupakan perspektif baru dalam bidang keilmuan arsitektur, dikarenakan Kuntowijoyo mengulas permasalahan tersebut dengan pendekatan ilmu sosial. Namun demikian dengan mencermati poin kedua dari solusi yang disampaikan Kuntowijoyo, terdapat beberapa penelitian yang memiliki kedekatan fokus dengan kegiatan penelitian ini, di antaranya adalah (1) Revitalisasi Fungsi Masjid Sebagai Pusat Ekonomi dan Dakwah Multikultural oleh Dalmeri yang dipublikasikan pada Jurnal Walisongo, Volume 22, Nomor 2, Edisi November 2014 [3]; (2) Peran Masjid Sebagai Roda Penggerak Perekonomian Masyarakat: Penelitian Deskriptif Pada PKL di Kawasan Masjid Al-Akbar Surabaya oleh Husniyah Suryani dan Siti Inayatul Faizah yang dipublikasikan pada Jurnal JESTT, Volume 2, Nomor 5, Edisi Mei 2015 [4]; (3) Revitalisasi Masjid Dalam Dialektika Pelayanan Umat dan Kawasan Perekonomian Rakyat oleh Ari Saputra dan Bayu Mitra Adhyatma Kusuma yang dipublikasikan pada Jurnal Al-Idarah, Volume 1, Nomor 1, Edisi Januari-Juni 2017 [5]; (4) Peranan Masjid Ar-Rahman Dalam Pembentukan Karakter Remaja Yang Religius di Desa Waekasar Kecamatan Waeapo Kabupaten Buru oleh Wakhidatul Khasanah, Samad Umarella, dan Ainun Diana Lating yang dipublikasikan pada Jurnal Kuttab, Volume 1, Nomor 1, Edisi Januari 2019 [6]. Empat makalah tersebut menekankan pada aspek peran masjid, sehingga memiliki kedekatan fokus dengan penelitian ini, tetapi memiliki perbedaan pada dua aspek, meliputi (1) penelitian sebelumnya menekankan pada bidang ekonomi dan dakwah, sedangkan penelitian ini menekankan pada bidang sosial keagamaan; dan (2) penelitian ini menjadikan masjid kampus sebagai objek penelitian, sementara penelitian sebelumnya fokus pada kajian masjid permukiman dan masjid jami'. Dari kebaruannya pada aspek permasalahan dan objek penelitian, hasil penelitian ini memberikan manfaat teoritis dengan meluaskan kajian dan memperkaya khazanah keilmuan arsitektur, terutama di bidang arsitektur masjid yang merupakan bagian dari paradigma keilmuan Arsitektur Islam.

\subsection{Kerangka Teori}

Ditinjau dari bidang arsitektur, peran masjid kampus sebagai salah satu dari lima poin solusi terhadap permasalahan Generasi Muslim Tanpa Masjid merujuk pada aspek fungsi masjid dan organisasi ruang masjid. Dimulai dari aspek pertama, secara konseptual penentuan fungsi masjid berdasarkan pada gagasan masjid sebagai ruang suci yang oleh Gazalba $(1994: 111,119)$ dinyatakan sebagai unsur utama masjid yang bermakna bahwa masjid secara spasial memiliki sifat sakral sekaligus profan atau berorientasi akhirat sekaligus dunia [7]. Gazalba (1994: 108) menetapkan dua hukum perimbangan berdasarkan gagasan masjid tersebut, yakni (1) perimbangan hubungan dengan Allah, manusia dan alam; dan (2) perimbangan antara kehidupan dunia dan akhirat.

Fungsi masjid yang merupakan derivasi dari gagasan masjid sebagai ruang suci yang terikat dengan dua hukum perimbangan, merujuk pada Rifa'i dan Fakhruroji (2005: 45), meliputi (1) fungsi utama atau fungsi Tauhid yakni kegiatan yang tergolong ibadah maghdah sebagai realisasi dari hubungan antara manusia dengan Tuhan; dan (2) fungsi pendukung, yakni seluruh kegiatan yang tergolong ibadah ghairu maghdah sebagai realisasi dari hubungan antar sesama manusia dan antara manusia dan alam [8]. Dilandasi gagasan masjid, maka fungsi utama masjid bernilai sakral yang berorientasi secara langsung pada kehidupan akhirat dan fungsi pendukung masjid bernilai profan yang berorientasi secara langsung pada kehidupan dunia. Dua jenis fungsi masjid tersebut dengan karakternya masing-masing menunjukkan ciri khas ajaran Islam yang melingkupi dimensi dunia dan akhirat, atau dalam pernyataan Rifa'i dan Fakhruroji (2005: 7), masjid memiliki peran sebagai sarana ibadah kepada Allah yang berdimensi ukhrawi sekaligus sarana sosial pembinaan masyarakat yang berdimensi duniawi. 
Rifa'i dan Fakhruroji (2005: 46) menyatakan, dua jenis fungsi masjid tidaklah saling terpisah dan meniadakan, tetapi merupakan kategori yang saling melengkapi, terintegrasi, dan bersifat komplementer untuk suatu masjid dapat mencapai tujuan pendirian dan pembinaannya oleh umat Islam, sebagaimana merujuk pada Gazalba (1994: 326), tidak lain ialah untuk terwujudkan keselamatan hidup dan kesejahteraan kehidupan umat Islam. Oleh sebab itu agar masjid dapat mencapai tujuannya tersebut kedua jenis fungsi masjid memiliki karakter yang berbeda. Qaradhawi (2000: 101) menjelaskan, fungsi utama masjid bersifat statis yang berlaku sepanjang zaman dan di mana pun masjid didirikan dan dibina oleh umat Islam, sementara fungsi pendukung masjid bersifat dinamis yang senantiasa harus mengalami penyesuaian, perubahan, dan perkembangan seiring perubahan zaman yang mempengaruhi kondisi kehidupan dan kebutuhan hidup umat Islam pada suatu ruang dan waktu tertentu [9].

Aspek kedua dari peran masjid kampus ditinjau secara arsitektural adalah tata ruang masjid yang memiliki karakter dan konfigurasi berdasarkan jenis dan hirarki fungsi masjid. Kembali merujuk pada pernyataan Rifa'i dan Fakhruroji (2005: 45), fungsi utama masjid yang meliputi ibadah maghdah menempatkan ruang shalat pada hirarki tertinggi diantara ruang-ruang lainnya di masjid, sehingga menjadikannya sebagai pusat ruang masjid. Fanani (2009: 244) menggarisbawahi, dikarenakan masjid dari aspek fungsionalnya tidak hanya mewadahi kegiatan ibadah maghdah, maka tata ruang masjid tidak hanya terdiri dari ruang shalat [10]. Serambi masjid yang secara historis tidak dapat dipisahkan dari keberadaan ruang Shuffah di Masjid Nabawi diperuntukkan untuk mewadahi fungsi pendukung masjid yang bersifat dinamis, sehingga menjadikannya bersifat kontekstual ditandai dengan keragaman fungsi dan bentuk serambi masjid dari berbagai periode zaman dan tempat kehidupan umat Islam. Dengan demikian dapat ditelusuri secara historis bahwasanya ruang-ruang di masjid yang mewadahi fungsi pendukung masjid merupakan perkembangan dari ruang serambi yang disebabkan perkembangan fungsi pendukung masjid mempengaruhi perubahan ruang serambi hingga dipisahkan ke dalam ruang tersendiri yang masih berada di dalam area masjid.

Dari pembahasan kajian referensi di atas, maka peran masjid kampus dalam merealisasikan agenda integrasi Generasi Muslim Tanpa Masjid ke dalam jamaah umat Islam yang merupakan fokus dari kegiatan penelitian ini merujuk pada (1) aspek fungsi masjid yang terdiri dari fungsi utama dan fungsi pendukung; dan (2) aspek tata ruang masjid yang terdiri dari ruang shalat untuk mewadahi kegiatan utama dan ruang serambi serta ruang-ruang lainnya yang diperuntukkan untuk mewadahi kegiatan pendukung masjid. Dengan kerangka teoritik tersebut, kegiatan penelitian ini akan mengidentifikasi fungsi utama dan fungsi pendukung masjid kampus UMS, serta konfigurasi tata ruang untuk mewadahi fungsi masjid dalam rangka menarik keterlibatan Generasi Muslim Tanpa Masjid berkegiatan di masjid kampus UMS. Setelah diketahui fungsi dan konfigurasi tata ruangnya, maka dapat diidentifikasi strategi dan langkah-langkah untuk mengintegrasikan Generasi Muslim Tanpa Masjid ke dalam jamaah umat Islam berdasarkan pengalaman civitas akademika UMS. Simpulan dari kerangka teori yang digunakan dalam penelitian ini dan keterkaitannya dengan tujuan penelitian, dapat ditampilkan dalam gambar 1 di bawah ini:

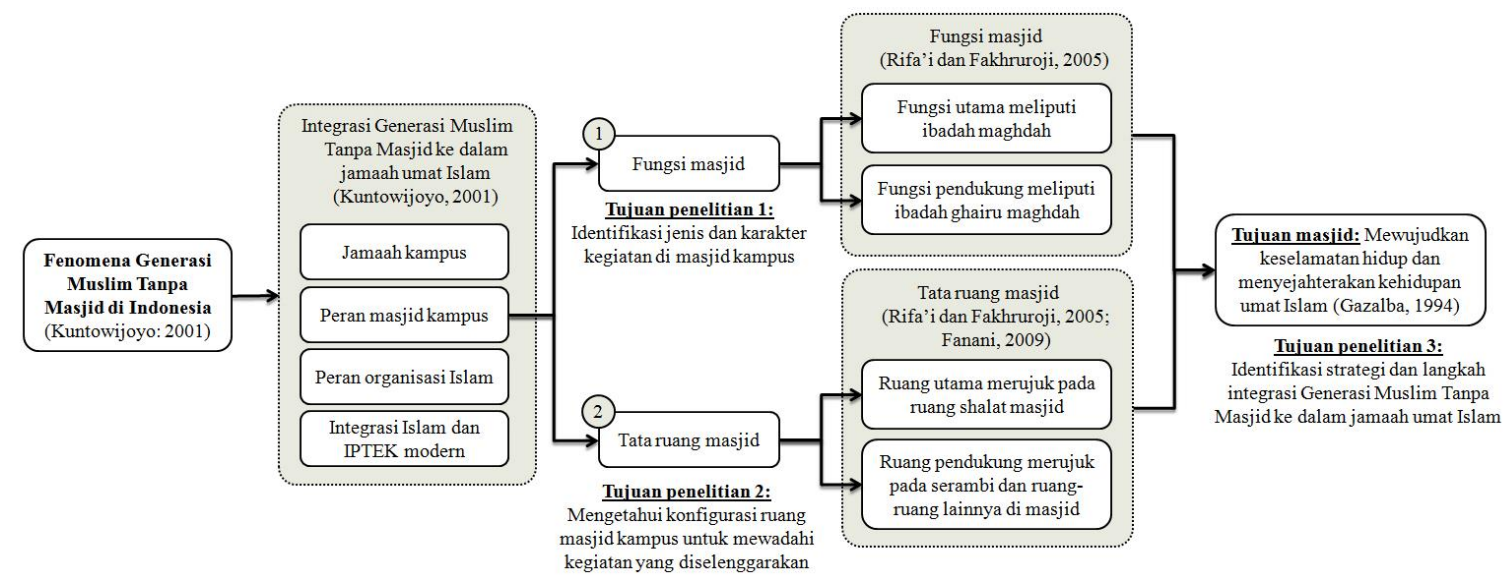

Gambar 1. Kerangka teori

Sumber : Analisa, 2020 


\section{METODOLOGI}

Metode penelitian yang digunakan untuk menemukan jawaban atas rumusan masalah yang diangkat adalah induksi-kualitatif dengan variabel (1) kegiatan atau fungsi; dan (2) organisasi ruang. Nalar induktif yang digunakan dalam penelitian ini bermakna bahwa variabel penelitian sebatas digunakan sebagai panduan dalam pengumpulan data, kategorisasi data, dan analisa data, bukan digunakan untuk menguji variabel maupun memverifikasi objek penelitian berdasarkan variabel yang digunakan. Dengan demikian, nalar induktif menjadikan hasil penelitiani ini bersifat spesifik karena terikat pada objek studi kasus. Namun dikarenakan fenomena Generasi Muslim Tanpa Masjid merebak di berbagai kota modern di Indonesia dengan kesamaan karakter yang dimiliki, hasil penelitian ini dapat diterapkan pada masjid kampus di perguruan tinggi lainnya di Indonesia setelah dikontekstualisasikan dengan kondisi dan karakter lingkungan objek studi setempat.

Dari 4 lokasi kampus Universitas Muhammadiyah Surakarta, dipilih kampus 1 dan kampus 2 sebagai lokus kegiatan penelitian berdasarkan dua pertimbangan. Pertama, pusat kegiatan pendidikan yang melibatkan mayoritas civitas akademika UMS terdapat di kampus 1 yang dari aspek historisnya merupakan awal mula keberadaan UMS, dan di kampus 2 yang selain mewadahi kegiatan pendidikan juga merupakan pusat kegiatan administrasi di lingkungan UMS yang ditandai dengan keberadaan Gedung Rektorat Siti Walidah. Kedua, masjid kampus UMS dengan kualitas yang signifikan dari aspek kapasitas ruang dan bentukan arsitekturalnya terdapat di area kampus 1 dan kampus 2 UMS, yakni Masjid Fadlurrahman di area kampus 1 UMS dan Masjid Sudalmiyah Rais di area kampus 2 UMS (lihat gambar 2).

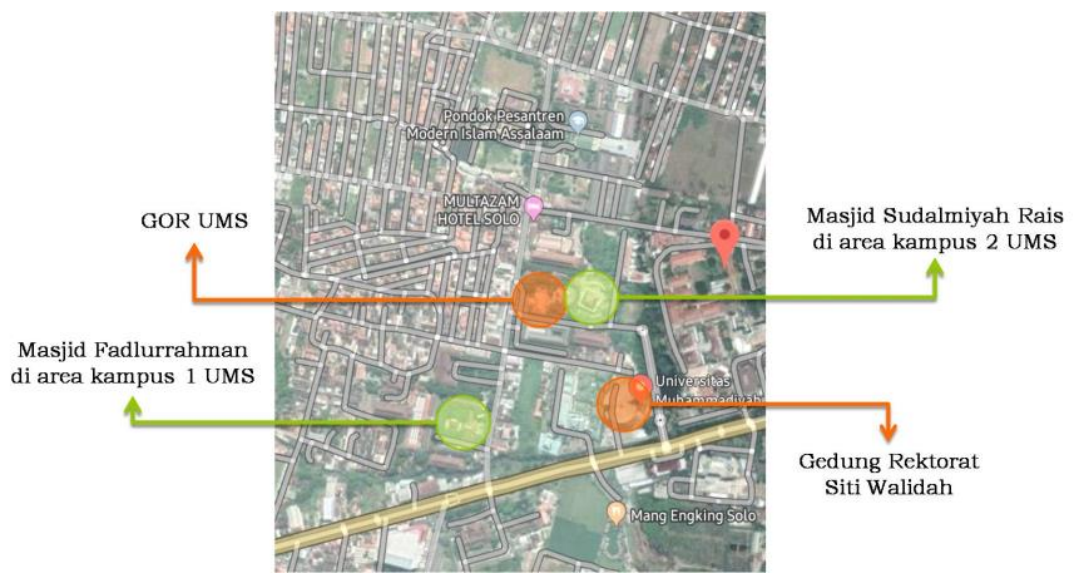

Gambar 2. Peta lokasi lokus penelitian di area kampus 1 dan kampus 2 UMS Sumber: diolah dari pencitraan Google Map, 2019

Metode pengumpulan data yang digunakan dalam penelitian ini terdiri dari (1) observasi terhadap variabel amatan meliputi kegiatan yang dilakukan penulis maupun kegiatan yang diselenggarakan berbagai pihak civitas akademika UMS di masjid kampus UMS, serta organisasi ruang masjid kampus UMS; dan (2) wawancara kepada Dr. Syamsul Hidayat selaku Ketua Takmir Masjid Kampus UMS dan kepada pihak penyelenggara kegiatan di masjid kampus UMS dengan menggunakan teknik wawancara semi terstruktur berpandukan variabel penelitian yang diarahkan pada tujuan penelitian. Selain metode observasi dan wawancara, penelitian ini juga menggunakan pengalaman penulis yang bersifat eksperimental sebagai data. Otoritas penulis sebagai sumber data didasari dua hal, yakni (1) penulis pada masa lalu merupakan bagian dari Generasi Muslim Tanpa Masjid yang pernah mengalami integrasi ke dalam jamaah umat Islam; dan (2) status penulis sebagai dosen Prodi Arsitektur UMS dan Wakil Ketua Pusat Studi Arsitektur Islam UMS yang memiliki kewenangan untuk menyelenggarakan kegiatan pendidikan dan penelitian di masjid kampus UMS dengan melibatkan mahasiswa, organisasi kemahasiswaan, dan unit kegiatan mahasiswa yang secara struktural berada di bawah otoritas Prodi Arsitektur UMS. 
Pemilihan metode pengumpulan data di atas berdasarkan pada jenis data yang dibutuhkan untuk menjawab rumusan masalah, yakni terdiri dari (1) data fisik berupa dokumentasi kegiatan dan unsur arsitektural masjid yang memperlihatkan tata ruang masjid; dan (2) data non fisik berupa pemaparan deskriptif dan analitik kegiatan yang diselenggarakan di masjid kampus UMS melalui keterlibatan secara langsung dalam kegiatan, wawancara kepada pihak penyelenggara kegiatan, atau wawancara kepada pihak pengelola masjid kampus UMS. Analisa data dilakukan secara naratif-kualitatifinterpretatif untuk memaknai data agar selaras dengan konteks, lingkup, dan tujuan penelitian, sehingga akan didapatkan temuan penelitian yang dapat menjawab rumusan masalah. Dengan metode analisa ini, data fisik dan data non fisik dikategorikan dan dianalisa berdasarkan variabel amatan untuk didapatkan temuan penelitian yang menjawab rumusan masalah 1 dan 2. Dengan metode yang sama, 2 temuan penelitian sebelumnya diabstraksi secara interpretatif untuk didapatkan temuan penelitian yang menjawab rumusan masalah 3 . Setelahnya penegasan terhadap temuan penelitian yang bersifat kritis disampaikan pada bagian kesimpulan yang merupakan bagian akhir dari makalah ini.

\section{HASIL DAN PEMBAHASAN}

Analisa data untuk mendapatkan temuan penelitian yang menjawab rumusan masalah 1 dan 2 dilakukan berdasarkan variabel penelitian yang dijabarkan dalam dua subbab pada bagian ini. Pada subbab ketiga dilakukan pembahasan dua temuan penelitian sebelumnya untuk mendapatkan jawaban atas rumusan masalah 3 .

\subsection{Fungsi Masjid Kampus}

Fungsi masjid kampus UMS berkaitan dengan kegiatan yang diselenggarakan di masjid kampus UMS untuk menarik keterlibatan Generasi Muslim Tanpa Masjid di masjid kampus. Analisa bagian ini dibedakan berdasarkan otoritas pelaksana kegiatan meliputi pihak (1) universitas; (2) prodi; (3) organisasi kemahasiswaan; dan (4) unit kegiatan mahasiswa.

\subsubsection{Pihak universitas}

Pihak universitas memiliki dua program yang diselenggarakan di masjid kampus dengan tujuan untuk meningkatkan pemahaman keislaman seluruh civitas akademika UMS. Program pertama yang diwajibkan kepada seluruh mahasiswa baru UMS adalah mentoring agama Islam yang diselenggarakan oleh LPPIK UMS untuk meningkatkan pemahaman keislaman mahasiswa baru di lingkungan UMS. Program mentoring yang diselenggarakan pada semester 1 dan berlangsung sepanjang 1 semester dibuka dengan kegiatan grand opening dalam format pengajian akbar yang bertempat di Masjid Sudalmiyah Rais kampus 2 UMS (lihat gambar 3). Sementara pelaksanaan kegiatan rutin mentoring setiap hari Sabtu diselenggarakan di sekitar area Masjid Fadlurrahman kampus 1 UMS dan Masjid Sudalmiyah Rais kampus 2 UMS (lihat gambar 3).
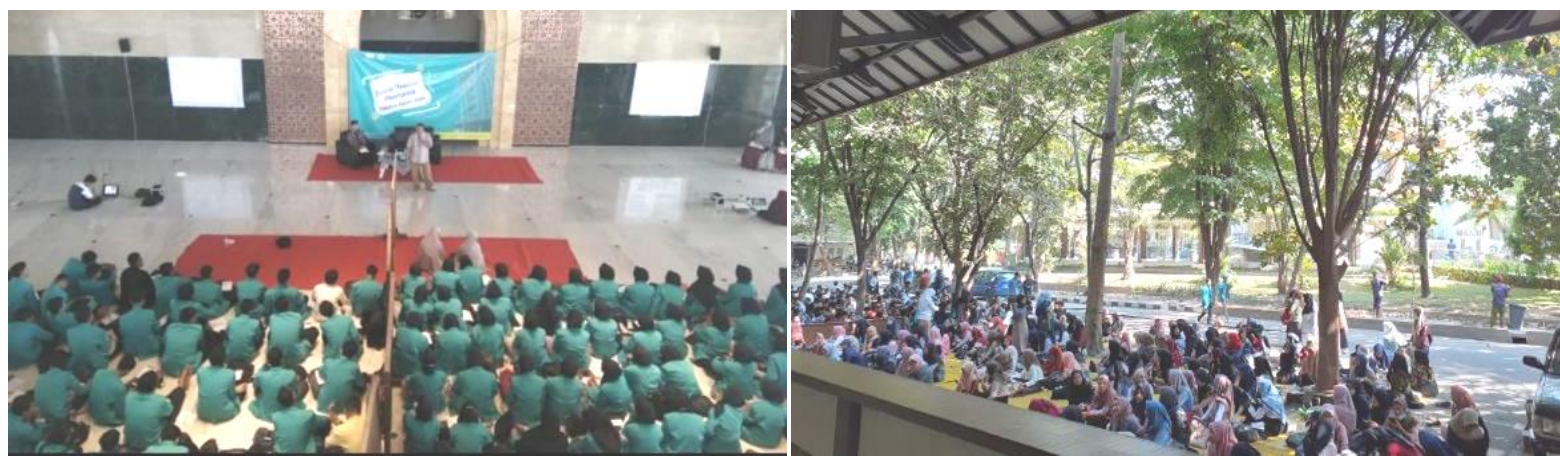

Gambar 3. Grand opening mentoring agama Islam di Masjid Sudalmiyah Rais kampus 2 UMS (kiri), dan kegiatan mentoring di sekitar area Masjid Sudalmiyah Rais kampus 2 UMS (kanan) Sumber: Suryo Satrio Aji Wiralaksono, 2019 (kiri), Hasil Survey, 2019 (kanan) 
Syamsul Hidayat (2019) menjelaskan, diselenggarakannya kegiatan grand opening mentoring agama Islam di Masjid Sudalmiyah Rais dan penyelenggaraan mentoring setiap pekan di sekitar area masjid kampus UMS dikarenakan kegiatan mentoring memiliki muatan keislaman, sehingga sesuai dengan peruntukkan masjid sebagai tempat peribadatan umat Islam, selain juga bertujuan untuk menumbuhkan ikatan personal mahasiswa baru dengan masjid kampus melalui kegiatan keislaman.

Progam kedua yang diselenggarakan pihak universitas di masjid kampus UMS bertajuk UMS Cinta Shubuh, yakni kegiatan shalat Shubuh berjamaah di masjid kampus UMS bagi seluruh civitas akademika UMS yang dilanjutkan dengan pengajian dan sarapan pagi bersama.

Dua kegiatan tersebut yang diselenggarakan oleh pihak universitas di masjid kampus merupakan fungsi pendidikan masjid kampus dengan sifat yang berbeda untuk masing-masing kegiatan. Kegiatan mentoring agama Islam bersifat wajib bagi seluruh mahasiswa UMS, sehingga berpotensi dapat menarik keterlibatan seluruh Generasi Muslim Tanpa Masjid dari kalangan mahasiswa untuk berkegiatan di masjid kampus, sedangkan kegiatan UMS Cinta Shubuh tidak sekuat kegiatan mentoring untuk menarik keterlibatan civitas akademika UMS berkegiatan di masjid kampus karena sifatnya sebatas himbauan untuk diikuti.

\subsubsection{Pihak Prodi}

Dalam lingkup Prodi Arsitektur UMS, kegiatan yang diselenggarakan di masjid kampus UMS sekaligus merupakan pengalaman penulis adalah kegiatan perkuliahan, diantaranya ialah kuliah umum Studio Perancangn Arsitektur (STUPA) bertempat di ruang semi-basement Masjid Sudalmiyah Rais kampus 2 UMS (lihat gambar 4) dan kegiatan pameran tugas mata kuliah Arsitektur Masjid di serambi lengkung Masjid Sudalmiyah Rais kampus 2 UMS (lihat gambar 4). Selain Prodi Arsitektur, juga terdapat prodi lain yang memanfaatkan masjid kampus untuk melangsungkan kegiatan pendidikan, sebagaimana disampaikan Syamsul Hidayat (2019), salah satunya adalah Prodi Pendidikan Olahraga yang menyelenggarakan perkuliahan praktik olahraga di ruang serbaguna Masjid Fadlurrahman kampus 1 UMS.
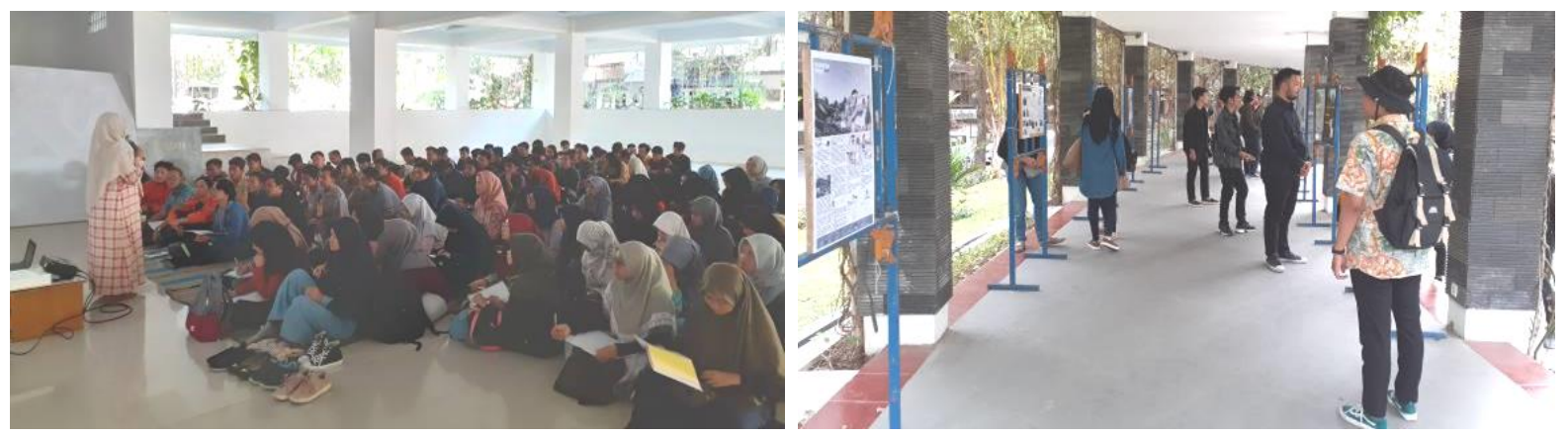

Gambar 4. Perkuliahan STUPA di Masjid Sudalmiyah Rais kampus 2 UMS (kiri), dan pameran tugas Arsitektur Masjid di serambi lengkung Masjid Sudalmiyah Rais kampus 2 UMS (kanan) Sumber: Hasil Survey, 2019

Kegiatan perkuliahan di bawah otoritas prodi yang diselenggarakan di masjid kampus di lingkungan UMS merupakan fungsi pendidikan masjid kampus yang bersifat wajib bagi mahasiswa yang berstatus sebagai peserta mata kuliah, sehingga dapat menarik keterlibatan Generasi Muslim Tanpa Masjid dari kalangan mahasiswa untuk berkegiatan di masjid kampus.

\subsubsection{Pihak organisasi kemahasiswaan}

Kegiatan di masjid kampus UMS yang diselenggarakan pihak organisasi kemahasiswaan meliputi kegiatan rutin organisasi yang diperuntukkan bagi kalangan internal dan pelaksanaan program kerja organisasi yang diperuntukkan bagi mahasiswa UMS secara umum. Salah satu kegiatan rutin organisasi yang diselenggarakan di Masjid Sudalmiyah Rais kampus 2 UMS adalah rapat rutin dan rapat kepanitiaan IMM Averroes komisariat Fakultas Teknik UMS. Sementara program kerja yang telah 
dilaksanakan IMM Averroes di Masjid Sudalmiyah Rais kampus 2 UMS diantaranya adalah sekolah kepenulisan dan pemutaran film (lihat gambar 5). Menurut Suryo Satrio Aji Wiralaksono (2019) sebagai pengurus IMM Averroes, diselenggarakannya program tersebut bertujuan untuk menarik keterlibatan mahasiswa non kader, sedangkan ditetapkannya masjid sebagai tempat untuk menyelenggarakan acara bertujuan untuk membentuk pemahaman mahasiswa bahwasanya masjid merupakan pusat kegiatan keilmuan dalam lingkup yang luas bagi umat Islam.
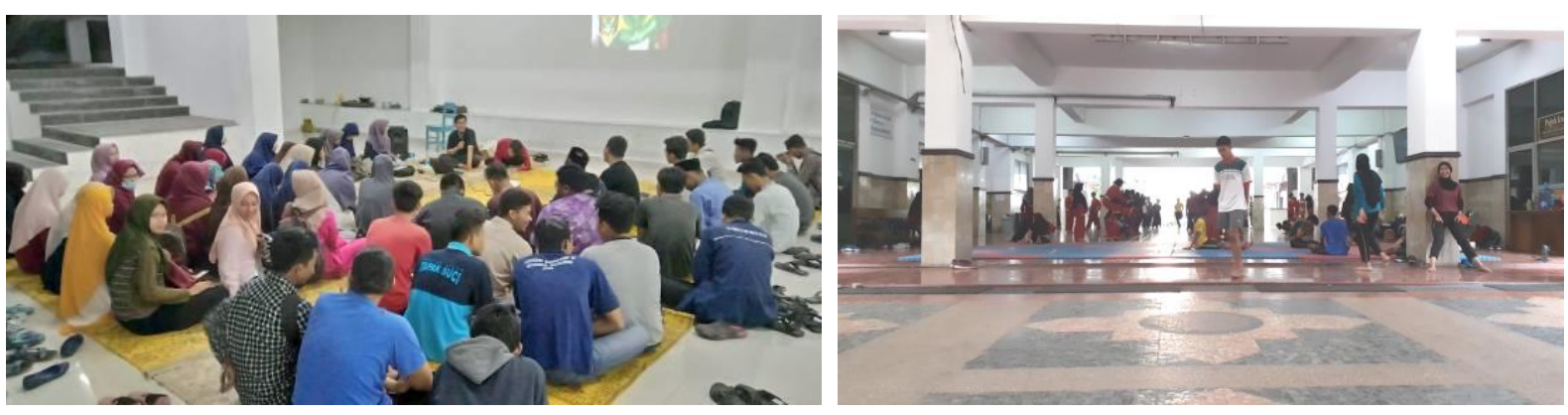

Gambar 5. Diskusi film di ruang serbaguna Masjid Sudalmiyah Rais kampus 2 UMS (kiri), dan latihan beladiri dan olahraga oleh unit kegiatan mahasiswa di ruang serbaguna Masjid Fadlurrahman kampus 1 UMS (kanan)

Sumber: Dinullah, 2018 (kiri), Hasil Survey, 2019 (kanan)

Dalam lingkup organisasi kemahasiswaan Prodi Arsitektur UMS yang juga merupakan pengalaman penulis, program kerja yang diselenggarakan oleh pihak Keluarga Mahasiswa Teknik Arsitektur UMS di Masjid Sudalmiyah Rais kampus 2 UMS meliputi diskusi menjelang berbuka puasa sekaligus buka puasa bersama pada bulan Ramadhan $1440 \mathrm{H}$ yang diperuntukkan bagi seluruh mahasiswa Prodi Arsitektur UMS.

Kegiatan rutin organisasi dakwah kampus yang diselenggarakan di masjid kampus UMS, seperti rapat rutin dan rapat koordinasi tidak melibatkan Generasi Muslim Tanpa Masjid karena pihak pengurus merupakan kader yang sejak awal memiliki ikatan personal, sosial, dan intelektual dengan masjid. Namun demikian sebagai organisasi dakwah kampus, program kerja IMM Averroes yang tidak secara eksplisit menampilkan muatan keislaman dan keorganisasian membuka kemungkinan keterlibatan Generasi Muslim Tanpa Masjid berkegiatan di masjid kampus UMS. Sedangkan program kerja organisasi kemahasiswaan selain organisasi dakwah kampus, seperti himpunan mahasiswa prodi, berpotensi lebih luas menarik keterlibatan Generasi Muslim Tanpa Masjid dikarenakan sifat organisasi yang tidak spesifik bergerak di bidang dakwah dengan menjadi bagian dari kepengurusan organisasi maupun sebagai pihak yang terlibat dalam program kerja organisasi. Seluruh kegiatan tersebut yang diselenggarakan pihak organisasi kemahasiswaan dapat dikategorikan sebagai fungsi dakwah masjid kampus, baik secara eksplisit maupun implisit, yang bertujuan mengajak civitas akademika UMS dari kalangan mahasiswa untuk mempelajari Islam, mendekatkan diri dengan masjid, dan menjadi bagian dari komunitas umat Islam.

\subsubsection{Pihak unit kegiatan mahasiswa}

Kegiatan di masjid kampus UMS yang diselenggarakan oleh pihak unit kegiatan mahasiswa, menurut Syamsul Hidayat (2019), terbatas pada jenis kegiatan yang bermuatan keislaman atau kegiatan yang memiliki keterkaitan dengan masjid. Untuk unit kegiatan mahasiswa yang tidak berkaitan dengan keislaman secara langsung, seperti basket, paduan suara, dan drumband, kegiatan diselenggarakan di sekitar masjid kampus UMS, seperti di GOR UMS atau lapangan universitas yang lokasinya berdekatan dengan Masjid Sudalmiyah Rais kampus 2 UMS. Sementara itu di Masjid Fadlurrahman kampus 1 UMS secara rutin diselenggarakan latihan beladiri dan olahraga oleh unit kegiatan mahasiswa di ruang serbaguna masjid (lihat gambar 5).

Walaupun tidak menyelenggarakan kegiatan di masjid kampus, menurut Syamsul Hidayat (2019), peran masjid kampus tetap penting untuk mengontrol kegiatan unit kegiatan mahasiswa, diantaranya adalah 
suara adzan dari masjid sebagai penanda waktu bagi mahasiswa menghentikan kegiatan untuk menuju masjid dan melaksanakan shalat berjamaah di masjid kampus.

Kecenderungan yang terjadi pada kegiatan yang diselenggarakan oleh unit kegiatan mahasiswa memiliki kesamaan dengan lingkup organisasi kemahasiswaan, yakni unit kegiatan mahasiswa yang tidak secara eksplisit berkaitan dengan kegiatan keislaman dan dakwah Islam dapat menarik keterlibatan Generasi Muslim Tanpa Masjid untuk berkegiatan di masjid atau di area sekitar masjid. Bahkan daya tarik yang dimiliki unit kegiatan mahasiswa lebih kuat untuk menarik keterlibatan Generasi Muslim Tanpa Masjid dibandingkan organisasi kemahasiswaan karena sifat komunitas yang lebih fleksibel serta berdasarkan minat dan bakat, sehingga memiliki lingkup kegiatan yang luas yang dapat dikategorikan sebagai fungsi pendidikan, fungsi olahraga, hingga fungsi rekreasi masjid kampus.

\subsection{Organisasi Ruang}

Berbagai kegiatan yang diselenggarakan di masjid kampus UMS oleh pihak universitas, prodi, organisasi kemahasiswaan, dan unit kegiatan mahasiswa, memanfaatkan dua ruang di area masjid kampus UMS, yakni ruang utama masjid dan ruang serbaguna masjid. Ruang serbaguna di Masjid Fadlurrahman kampus 1 UMS terdapat di lantai 1, tepat di bawah ruang utama masjid, dengan bentuk hall terbuka di kedua sisi yang selain diperuntukkan untuk mewadahi beragaman kegiatan yang berkaitan dengan perkuliahan, kemahasiswaan maupun kegiatan masjid, juga merupakan jalur sirkulasi menuju ruang kelas dan Auditorium Djazman dari arah masjid. Syamsul Hidayat (2019) menyatakan, secara fungsional ruang hall Masjid Fadlurrahman merupakan perluasan ruang shalat jika ruang utama masjid tidak dapat mewadahi jamaah, seperti pada pelaksaan kegiatan UMS Cinta Shubuh. Menurut Syamsul Hidayat (2019) posisi ruang hall di lantai 1 sebagai perluasan ruang utama masjid tidaklah bermasalah dalam pelaksanaan ibadah shalat berjamaah karena jamaah yang berada di lantai 1 tetap dapat mendengar suara imam yang berada di lantai 2 melalui teknologi pengeras suara.

Masjid Sudalmiyah Rais kampus 2 UMS memiliki dua ruang serbaguna. Pertama adalah ruang serambi lengkung masjid yang berada di sisi kiri dan kanan area masjid, atau di sisi Utara dan Selatan bangunan utama masjid dengan bentuk terbuka di empat sisi yang difungsikan sebagai jalur sirkulasi untuk memasuki ruang utama masjid dari keempat arah. Kedua adalah ruang semi-basement masjid dengan bentuk ruang terbuka di tiga sisi untuk memberikan fleksibilitas ruang yang tinggi agar dapat mewadahi beragam kegiatan, selain diperuntukkan pula sebagai jalur sirkulasi untuk memasuki ruang utama masjid dari arah Utara, Selatan, dan Barat.

Dua masjid kampus UMS yang menjadi objek studi kasus dalam penelitian ini memiliki konfigurasi ruang vertikal untuk hubungan antara ruang utama dan ruang serbaguna masjid. Pada Masjid Fadlurrahman kampus 1 UMS konfigurasi ruang vertikal terbentuk dari posisi ruang serbaguna di lantai 1 yang berada tepat di bawah ruang utama masjid di lantai 2 (lihat gambar 6). Sementara pada Masjid Sudalmiyah Rais kampus 2 UMS konfigurasi ruang vertikal terbentuk dari posisi ruang serambi lengkung yang memiliki elevasi lantai lebih rendah dari ruang utama masjid, dan ruang semi-basement masjid yang tepat berada di bawah ruang utama masjid (lihat gambar 7).

Dikaitkan dengan kegiatan yang diselenggarakan di ruang utama dan ruang serbaguna masjid kampus UMS dalam konteks realisasi agenda integrasi Generasi Muslim Tanpa Masjid ke dalam jamaah umat Islam, konfigurasi ruang masjid kampus UMS membentuk organisasi ruang utama-antara-luar. Zona utama merujuk pada ruang utama masjid yang diperuntukkan untuk melaksanakan ibadah shalat (berwarna hijau pada gambar 6 dan 7), zona antara merujuk pada ruang serbaguna masjid yang menghubungkan ruang utama masjid dengan ruang di luar area masjid (berwarna jingga pada gambar 6 dan 7), dan zona luar merujuk pada ruang-ruang di luar area masjid. 


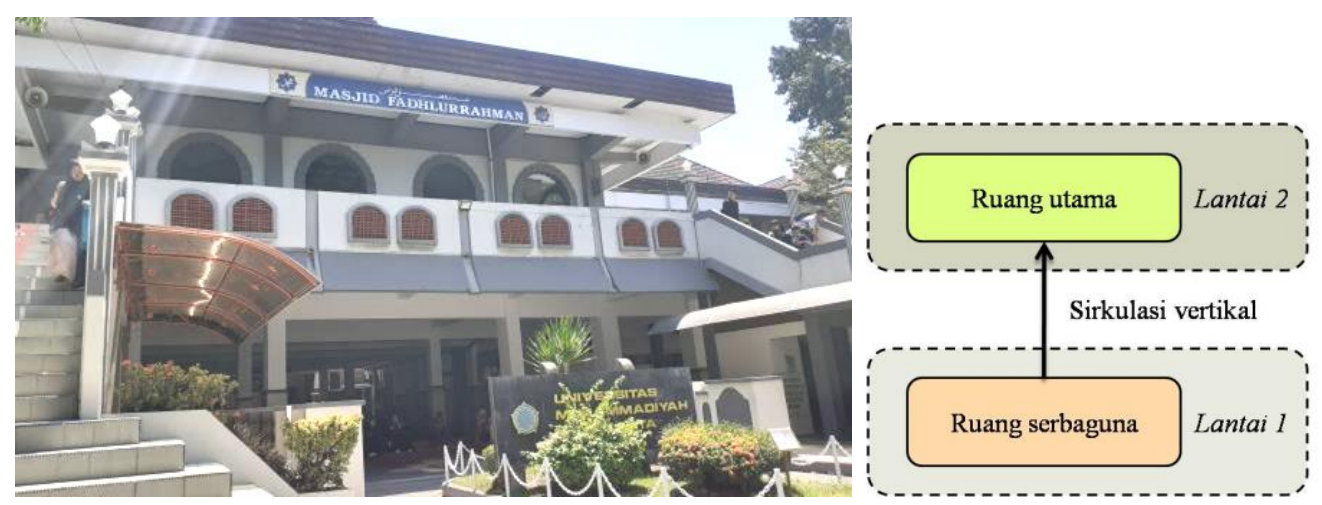

Gambar 6. Ruang hall serbaguna di bawah ruang utama Masjid Fadlurrahman kampus 1 UMS dengan konfigurasi ruang vertikal

Sumber: Hasil Survey, 2019 (kiri), analisa, 2019 (kanan)
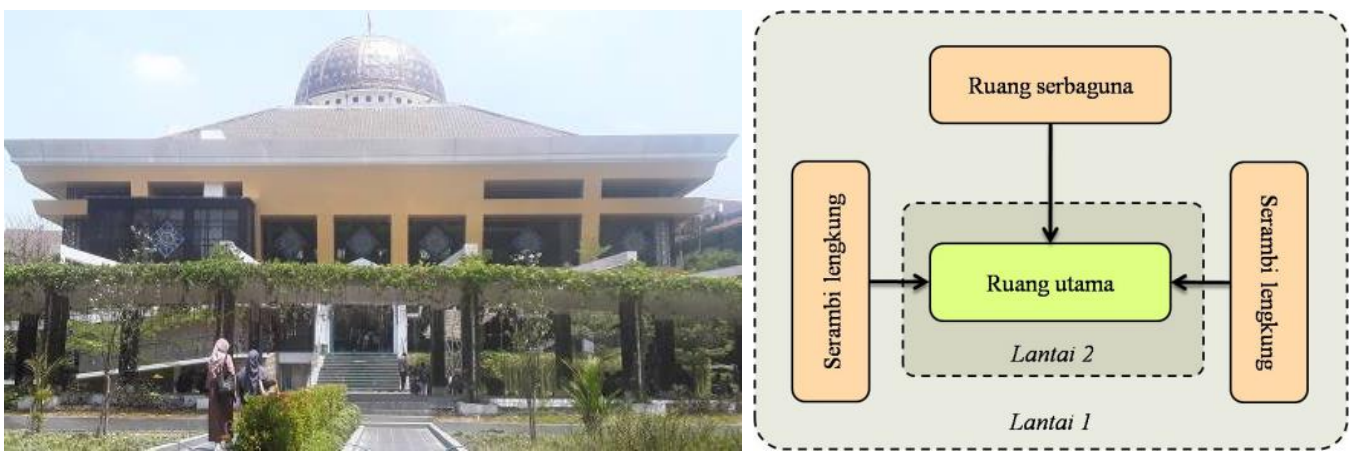

Gambar 7. Ruang serambi lengkung dengan elevasi lantai lebih rendah dari ruang utama Masjid Sudalmiyah Rais kampus 2 UMS dengan konfigurasi ruang vertikal Sumber: Shofi Syarifah, 2019 (kiri), analisa (kanan)

\subsection{Pembahasan}

Dari analisa pada bagian sebelumnya didapatkan dua temuan penelitian. Pertama, Kegiatan yang diselenggarakan oleh pihak universitas, prodi, organisasi kemahasiswa, dan unit kegiatan mahasiswa untuk menarik keterlibatan Generasi Muslim Tanpa Masjid berkegiatan di masjid kampus meliputi fungsi dakwah, pendidikan, olahraga, dan rekreasi yang merupakan fungsi pendukung masjid karena tergolong kegiatan ibadah ghairu maghdah. Terdapat perbedaan karakter kegiatan yang diselenggarakan oleh berbagai pihak civitas akademika UMS tersebut, di mana kegiatan yang diselenggarakan oleh pihak universitas dan prodi bersifat wajib, sehingga mengikat bagi Generasi Muslim Tanpa Masjid yang merupakan bagian dari civitas akademika UMS untuk terlibat berkegiatan di masjid kampus UMS. Sementara itu kegiatan yang diselenggarakan oleh pihak organisasi kemahasiswaan dan unit kegiatan mahasiswa bersifat terbuka dan sukarela didasari kesadaran individu sesuai dengan minat dan bakat masing-masing. Dengan demikian, temuan penelitian yang pertama adalah optimalisasi fungsi pendukung masjid kampus dengan sifat kegiatan yang beragam sangat penting dalam merealisasikan agenda integrasi Generasi Muslim Tanpa Masjid ke dalam jamaah umat Islam.

Beragam fungsi pendukung masjid kampus yang diselenggarakan ebrbagai pihak civitas akademika UMS bertujuan untuk menumbuhkan ikatan psikologis, sosial, dan intelektual Generasi Muslim Tanpa Masjid dengan masjid kampus. Ikatan personal dijalin dengan membiasakan keterlibatan Generasi Muslim Tanpa Masjid di lingkungan UMS melalui penyelenggaraan kegiatan yang tergolong ibadah ghairu maghdah di ruang serbaguna masjid kampus. Kegiatan mentoring yang diselenggarakan rutin oleh pihak universitas di sekitar area masjid kampus dapat difahami sebagai upaya membentuk kedekatan psikologis Generasi Muslim Tanpa Masjid dengan masjid kampus. Untuk ikatan sosial dijalin dengan dua cara, yakni (1) menarik Generasi Muslim Tanpa Masjid dalam kegiatan yang melibatkan jamaah kampus dalam skala besar seperti kegiatan grand opening mentoring yang diselenggarakan di ruang utama masjid maupun pengajian akbar dengan menghadirkan $d a^{\prime} i$ yang sedang digemari kalangan 
pemuda, sebagaimana dinyatakan oleh Syamsul Hidayat (2019); dan (2) dalam skala yang lebih kecil melalui kegiatan yang diselenggarakan oleh prodi dan pihak mahasiswa. Dan ikatan intelektual dijalin melalui peran jamaah kampus dengan menyelenggarakan fungsi dakwah dan pendidikan masjid kampus yang secara eksplisit bermuatan keislaman seperti pengajian dan mentoring maupun tidak secara langsung bermuatan keislaman, seperti kegiatan perkuliahan, diskusi, musyawarah, dan kegiatan olahraga.

Kedua, sebagai konsekuensi dari temuan pertama di atas, ruang serbaguna masjid kampus UMS yang merupakan zona-antara memiliki peran yang penting untuk menarik keterlibatan Generasi Muslim Tanpa Masjid berkegiatan di masjid kampus. Tanpa keberadaan zona-antara, realisasi agenda integrasi Generasi Muslim Tanpa Masjid ke dalam jamaah umat Islam memiliki dua hambatan, yakni (1) tanpa zona-antara tidak dapat diselenggarakan kegiatan pendukung di area masjid yang memiliki daya tarik bagi Generasi Muslim Tanpa Masjid dikarenakan zona-utama masjid memiliki fleksibilitas ruang yang rendah dengan tujuan untuk menjaga kesucian ruang shalat; dan (2) ketiadaan zona-antara di area masjid kampus menjadi hambatan psikologis bagi Generasi Muslim Tanpa Masjid untuk memasuki dan berkegiatan di zona-utama masjid, kecuali kegiatan yang diselenggarakan oleh pihak universitas dan prodi karena bersifat wajib dan mengikat. Dengan demikian organisasi ruang utama-antara-luar tidak saja didasari aspek fungsionalitas berkaitan dengan peruntukan fungsi ruang masjid, tetapi juga aspek psikologis kalangan Generasi Muslim Tanpa Masjid untuk mendatangi dan terlibat dalam kegiatan yang diselenggarakan di masjid.

Peran penting ruang serbaguna masjid kampus yang merupakan zona-antara dalam menarik keterlibatan Generasi Muslim Tanpa Masjid berkegiatan di masjid dilandasi dua prinsip. Pertama, aspek jumlah dan luasan zona-antara mempengaruhi tingkat daya tarik spasial masjid kampus bagi Generasi Muslim Tanpa Masjid. Masjid Sudalmiyah Rais kampus 2 UMS memiliki jumlah dan luasan zona-antara lebih banyak dan lebih luas dibandingkan Masjid Fadlurrahman kampus 1 UMS, sehingga memiliki daya tarik spasial yang lebih kuat karena dapat mewadahi beragam fungsi pendukung masjid dalam satu waktu dengan melibatkan jumlah yang lebih besar. Contoh di Masjid Sudalmiyah Rais kampus 2 UMS dapat diselenggarakan tiga kegiatan yang berbeda di serambi lengkung Utara, serambi lengkung Selatan, dan ruang semi-basement, sehingga dalam satu waktu Generasi Muslim Tanpa Masjid memiliki pilihan kegiatan yang banyak untuk berkegiatan di masjid.

Kedua, konfigurasi ruang mempengaruhi daya tarik spasial bagi Generasi Muslim Tanpa Masjid untuk mendatangi dan berkegiatan di masjid kampus. Konfigurasi ruang horizontal lebih mudah diakses secara fungsional dibandingkan konfigurasi ruang vertikal, dikarenakan mobilisasi spasial secara horizontal lebih mudah dilakukan secara fisikal daripada mobilisasi spasial secara vertikal. Poin ini menjadi kelemahan masjid kampus UMS dengan konfigurasi ruang vertikal. Namun dengan memperhatikan kondisi psikologis Generasi Muslim Tanpa Masjid yang tidak memiliki ikatan personal, sosial, dan intelektual dengan masjid, maka konfigurasi ruang vertikal dapat memberikan keuntungan berupa rasa nyaman ketika berkegiatan secara aktif di ruang serbaguna masjid karena terpisah secara vertikal dari ruang utama masjid yang memiliki daya tekan psikologis kuat bagi Generasi Muslim Tanpa Masjid.

Dua temuan penelitian ini, sebagaimana telah dijabarkan di atas, diabstraksi untuk mendapatkan temuan penelitian ketiga. Strategi yang diterapkan di masjid kampus UMS untuk merealisasikan agenda integrasi Generasi Muslim Tanpa Masjid ialah sinergi seluruh pihak civitas akademika UMS dari lingkup universitas dan prodi hingga lingkup kemahasiswaan melalui organisasi mahasiswa dan unit kegiatan mahasiswa untuk menjalin ikatan personal, sosial, dan intelektual Generasi Muslim Tanpa Masjid dengan masjid kampus di lingkungan UMS. Dengan mempertimbangkan aspek psikologis, realisasi agenda integrasi Generasi Muslim Tanpa Masjid ke dalam jamaah umat Islam di lingkungan UMS terdiri dari dua langkah. Langkah pertama berorientasi membentuk kebiasaan Generasi Muslim Tanpa Masjid berkegiatan di masjid kampus melalui penyelenggaraan ragam kegiatan pendukung masjid kampus. Langkah kedua berorientasi mengintegrasikan Generasi Muslim Tanpa Masjid ke dalam jamaah umat Islam dalam skala yang semakin luas hingga meliputi jamaah umat Islam di luar lingkungan kampus. 
Dua langkah tersebut dapat dilakukan secara beriringan maupun setahap demi setahap. Penanda telah terpenuhinya langkah pertama adalah dijadikannya area masjid kampus sebagai ruang jeda bagi civitas akademika di antara kegiatan akademis yang berlangsung di ruang kelas, seperti kegiatan istirahat atau berkumpul dalam nuansa non formal di ruang serbaguna masjid yang merupakan fungsi rekreasi masjid kampus (lihat gambar 8). Sementara terpenuhinya langkah kedua ditandai dengan berperan aktifnya organisasi Islam dalam berbagai program masjid kampus. Poin ini menjadi kekuatan masjid kampus UMS yang berada di bawah naungan Persyarikatan Muhammadiyah, sehingga tujuan integrasi Generasi Muslim Tanpa Masjid di lingkungan UMS ke dalam jamaah umat Islam hingga ke luar lingkungan kampus mampu untuk direalisasikan.
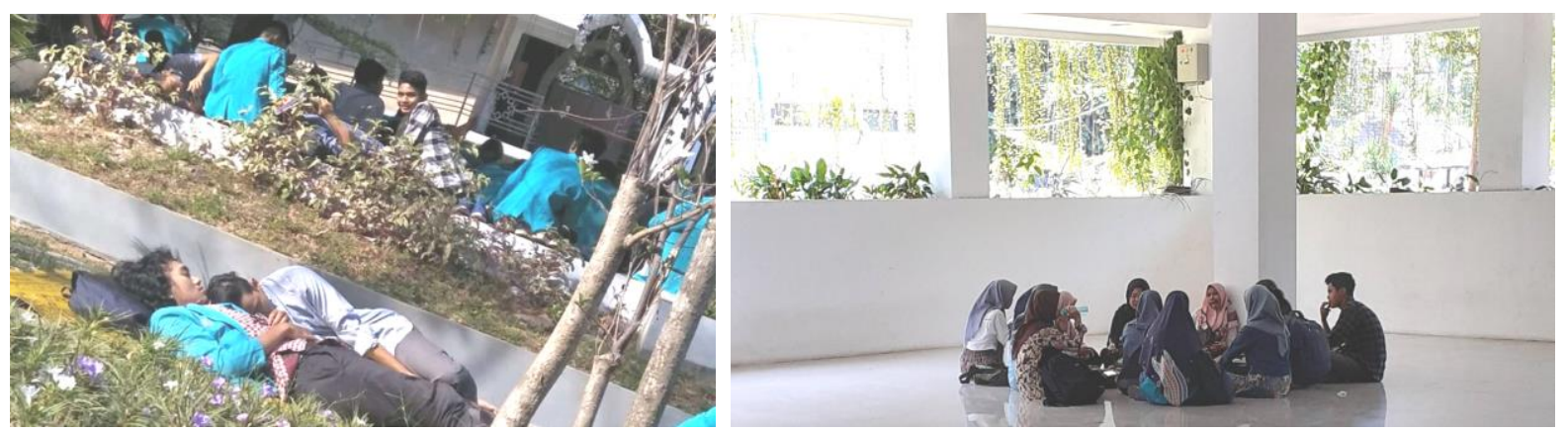

Gambar 8. Mahasiswa sedang beristirahat di serambi lengkung Masjid Sudalmiyah Rais kampus 2 UMS (kiri), dan kegiatan berkumpul mahasiswa dalam suasana non formal di ruang semi-basement Masjid Sudalmiyah Rais kampus 2 UMS (kanan)

Sumber: Suryo Satrio Aji Wiralaksono, 2019 (kiri), Hasil Survey, 2019 (kanan)

\section{SIMPULAN DAN SARAN}

Berdasarkan rumusan masalah, kegiatan penelitian ini menghasilkan tiga temuan sebagai berikut:

1. Kegiatan yang diselenggarakan di masjid kampus oleh berbagai pihak civitas akademika UMS dalam rangka merealisasikan agenda integrasi Generasi Muslim Tanpa Masjid ke dalam jamaah umat Islam meliputi fungsi dakwah, pendidikan, olahraga, dan rekreasi yang merupakan fungsi pendukung masjid kampus karena tergolong kegiatan ibadah ghairu maghdah dengan sifat kegiatan yang mengikat atau diwajibkan hingga terbuka dan sukarela.

2. Ruang serbaguna yang merupakan zona-antara sebagai ruang pendukung masjid kampus memiliki peran yang penting untuk menarik keterlibatan Generasi Muslim Tanpa Masjid di lingkungan UMS dengan konfigurasi ruang vertikal yang dapat memberikan rasa nyaman secara psikologis bagi Generasi Muslim Tanpa Masjid untuk terlibat dalam kegiatan di masjid kampus.

3. Strategi yang diterapkan berdasarkan pengalaman UMS dalam merealisasikan agenda integrasi Generasi Muslim Tanpa Masjid ke dalam jamaah umat Islam adalah sinergi seluruh civitas akademika UMS dengan dua langkah realisasi, yakni (1) berorientasi membentuk kebiasaan Generasi Muslim Tanpa Masjid melalui penyelenggaraan ragam kegiatan pendukung masjid kampus; dan (2) berorientasi mengintegrasikan Generasi Muslim Tanpa Masjid ke dalam jamaah umat Islam dalam skala yang luas.

Dari tiga kesimpulan di atas, penulis memiliki dua catatan kirits terkait realisasi agenda integrasi Generasi Muslim Tanpa Masjid ke dalam jamaah umat Islam, meliputi aspek kegiatan dan organisasi keruangan dengan mengeneralisasi hasil penelitian ini. Pada aspek kegiatan, agenda integrasi yang dilandasi strategi sinergi seluruh pihak civitas akademika tidak didasari kesadaran dan tanpa perencanaan. Realisasi agenda intergasi ke dalam jamaah umat Islam tidak secara formal merupakan kebijakan untuk menanggapi permasalahan Generasi Muslim Tanpa Masjid di lingkungan UMS, sehingga penyelenggaraan berbagai kegiatan di masjid kampus yang dijelaskan dalam penelitian ini dan keterkaitannya dengan permasalahan penelitian merupakan interpretasi serta abstraksi yang dilakukan oleh penulis. 
Konsekuensi tidak ditetapkannya agenda integrasi Generasi Muslim Tanpa Masjid sebagai kebijakan formal adalah minimnya peran universitas dan prodi secara struktural pada langkah pertama yang didominasi secara organik oleh pihak prodi, organisasi kemahasiswaan dan unit kegiatan mahasiswa. Syamsul Hidayat (2019) menyampaikan, salah satu tantangan yang dihadapi pihak takmir masjid kampus UMS adalah menjalin komunikasi dengan pihak fakultas dan prodi untuk menyelenggarakan program bersama di masjid kampus UMS. Jika tantangan ini dapat diselesaikan, maka peran pihak universitas melalui takmir masjid kampus UMS dan pihak Prodi akan semakin meningkat, misalnya dengan menetapkan peraturan jumlah minimal bagi mata kuliah jenis dan muatan tertentu untuk menyelenggarakan kegiatan perkuliahan yang terjadwal di area masjid kampus.

Catatan kedua pada aspek kegiatan adalah status UMS sebagai perguruan tinggi Islam justru membatasi peran masjid kampus dalam realisasi agenda integrasi Generasi Muslim Tanpa Masjid ke dalam jamaah umat Islam karena pengajaran agama dan mata kuliah yang muatan materinya berkaitan dengan agama maupun diintegrasikan dengan ajaran agama telah diselenggarakan di dalam kelas. Berbeda di lingkungan perguruan tinggi non Islam yang membatasi bahkan melarang dilakukannya kajian keagamaan dan integrasi IPTEK Modern dengan ajaran agama di ruang kelas, sehingga masjid kampus memiliki peran yang dominan dalam merealisasikan agenda integrasi Generasi Muslim Tanpa Masjid ke dalam jamaah umat Islam. Oleh karena itu dibutuhkan rumusan tersendiri bagi masjid kampus di lingkungan perguruan tinggi Islam untuk dapat berperan dominan dan optimal dalam menghadapi permasalahan Generasi Muslim Tanpa Masjid.

Poin terakhir dari aspek kegiatan ialah mengenai ragam kegiatan pendukung masjid kampus UMS yang spektrumnya terbatas pada fungsi dakwah, pendidikan, olahraga, dan rekreasi, sehingga belum mampu menarik keterlibatan Generasi Muslim Tanpa Masjid yang tidak memiliki minat dan bakat terhadap fungsi tersebut. Lingkup fungsi pendukung masjid kampus dalam rangka merealisasikan agenda integrasi Generasi Muslim Tanpa Masjid ke dalam jamaah umat Islam perlu diperluas mengikuti minat dan bakat di kalangan civitas akademika kampus. Hal ini menuntut dilakukannya penelitian mengenai keberadaan dan profil Generasi Muslim Tanpa Masjid di masing-masing lingkungan perguruan tinggi. Misal saja ruang serbaguna masjid kampus juga diperuntukkan untuk mewadahi fungsi seni dan kebudayaan, sehingga unit kegiatan mahasiswa yang berkaitan dengan bidang tersebut, di antaranya UKM teater, dapat berkegiatan di masjid kampus sekaligus sebagai upaya untuk mengontrol muatan dan kegiatan yang diselenggarakan agar selaras dengan Islam. Dengan mewadahi minat seluruh civitas akademika UMS, terutama dari kalangan Generasi Muslim Tanpa Masjid, maka dapat terwujud masjid kampus sebagai pusat kegiatan lingkar studi keislaman di lingkungan perguruan tinggi, sebagaimana solusi yang disampaikan oleh Kuntowijoyo.

Pada aspek organisasi ruang, penulis memiliki catatan, daya-tarik spasial masjid kampus UMS dapat ditingkatkan dengan memperluas ruang serbaguna masjid yang merupakan zonasi ruang-antara. Peningkatan daya-tarik spasial Masjid Fadlurrahman kampus 1 UMS dapat dilakukan dengan memasukkan Auditorium Djazman sebagai bagian dari ruang serbaguna masjid, sehingga secara psikologis pengguna yang berkegiatan di Auditorium Djazman akan merasa sedang terlibat dalam kegiatan di area masjid. Catatan ini perlu diperhatikan mengingat minimnya luasan ruang serbaguna Masjid Fadlurrahman yang seharusnya memiliki peran yang besar dalam menyelesaikan permasalahan Generasi Muslim Tanpa Masjid mengingat secara historis terkait dengan awal mula keberadaan UMS. Untuk Masjid Sudalmiyah Rais kampus 2 UMS, peningkatan daya-tarik spasial ruang serbaguna dapat dilakukan dengan memanfaatkan ruang halaman depan masjid sebagai ruang serbaguna yang diperuntukkan pula untuk mewadahi fungsi pendukung yang memiliki daya tarik bagi Generasi Muslim Tanpa Masjid agar terlibat dalam kegiatan yang dilangsungkan di masjid kampus (lihat gambar 9). 

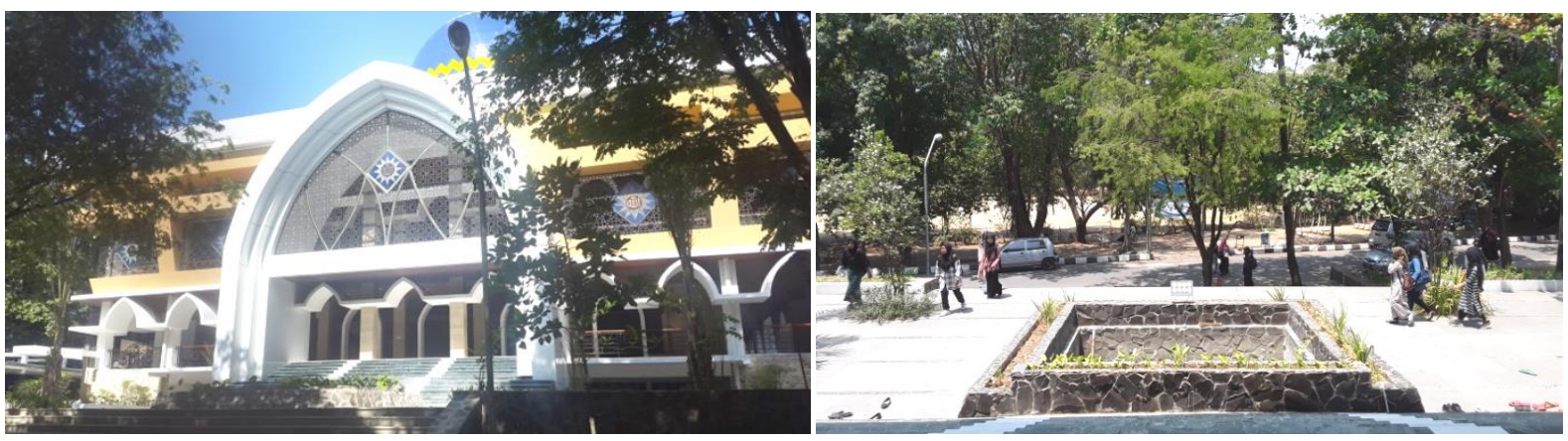

Gambar 9. Halaman depan Masjid Sudalmiyah Rais Kampus 2 UMS yang potensial untuk dimanfaatkan sebagai ruang serbaguna masjid kampus

Sumber: dokumentasi pribadi, 2019 (kiri), Shofi Syarifah, 2019 (kanan)

\section{UCAPAN TERIMA KASIH}

Penulis mengucapkan terima kasih kepada Dr. Syamsul Hidayat sebagai Ketua Takmir Masjid Kampus UMS karena telah mendukung penulis dalam melakukan kegiatan penelitian ini. Penulis juga berterimakasih kepada Suryo Satrio Aji Wiralaksono dan Shofi Syarifah atas bantuannya untuk mendokumentasikan Masjid Sudalmiyah Rais kampus 2 UMS dan mengumpulkan dokumentasi kegiatan yang diselenggarakan di masjid kampus UMS oleh berbagai pihak civitas akademika UMS.

\section{DAFTAR PUSTAKA}

[1] Kuntowijoyo, (2001), Muslim Tanpa Masjid, Penerbit Mizan, Bandung.

[2] Kuntowijoyo, (2006), Budaya dan Masyarakat, Penerbit Tiara Wacana, Yogyakarta.

[3] Dalmeri, (2014), Revitalisasi Fungsi Masjid Sebagai Pusat Ekonomi dan Dakwah Multikultural, Jurnal Walisongo, Volume 22, Nomor 2, Edisi November 2014, pp 321-350.

[4] Suryani, Husniyah dan Siti Inayatul Faizah, (2015), Peran Masjid Sebagai Roda Penggerak Perekonomian Masyarakat: Penelitian Deskriptif Pada PKL di Kawasan Masjid Al-Akbar Surabaya, Jurnal JESTT, Volume 2, Nomor 5, Edisi Mei 2015, pp 387-399.

[5] Saputra, Ari dan Bayu Mitra Adhyatma Kusuma, (2017), Revitalisasi Masjid Dalam Dialektika Pelayanan Umat dan Kawasan Perekonomian Rakyat, Jurnal Al-Idarah, Volume 1, Nomor 1, Edisi Januari-Juni 2017, pp 1-16.

[6] Khasanah, Wakhidatul, dkk, (2019), Peranan Masjid Ar-Rahman Dalam Pembentukan Karakter Remaja Yang Religius di Desa Waekasar Kecamatan Waeapo Kabupaten Buru, Jurnal Kuttab, Volume 1, Nomor 1, Edisi Januari 2019, pp 57-73.

[7] Gazalba, Sidi, (1994), Mesjid: Pusat Ibadah dan Kebudayaan Islam, Pustaka Al-Husna, Jakarta.

[8] Rifa'i, A. Bachrun dan Moch. Fakhruroji, (2005), Manajemen Masjid: Mengoptimalkan Fungsi Sosial-Ekonomi Masjid, Benang Merah Press: Bandung.

[9] Al-Qaradhawi, Yusuf, (2000), Tuntunan Membangun Masjid (terjemah), Gema Insani Press, Jakarta.

[10] Fanani, Achmad, (2009), Arsitektur Masjid, Bentang Pustaka, Yogyakarta. 